\title{
FIRST BRANCH OF OPHTHALMIC ARTERY AND ITS CLINICAL IMPORTANCE
}

\author{
ARTERIA OPHTHALMICA'NIN ILK DALI VE KLINIK ÖNEMI

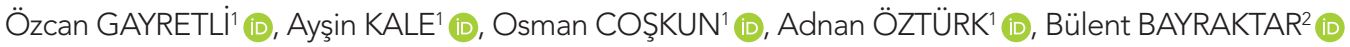 \\ IIstanbul University, Istanbul Faculty of Medicine, Department of Anatomy, Istanbul, Turkey \\ ${ }^{2}$ Istanbul University, Istanbul Faculty of Medicine, Department of Sports Medicine, Istanbul, Turkey
}

ORCID IDs of the authors: Ö.G. 0000-0001-7958-3170; A.K. 0000-0002-2305-420X; O.C. 0000-0002-0337-4927;

A.Ö. 0000-0002-5819-0543; B.B. 0000-0001-8102-4896

Cite this article as: Gayretli O, Kale A, Coskun O, Ozturk A, Bayraktar B. First branch of ophthalmic artery and its clinical importance. J Ist Faculty Med 2021;84(4):495-501. doi: 10.26650/IUITFD.2021.920797

\section{ABSTRACT}

Objective: The ophthalmic artery and its branches have one of the most complex anatomy and embryology of all arteries. Although many studies have been done on its branches, different references have given different conclusions about the first branch of it. Therefore, it was aimed to investigate the first branch of the ophthalmic artery in this study.

Materials and Method: Forty-one orbits of the cadavers, which belonged to the Department of Anatomy of Istanbul Faculty of Medicine, were examined.

Results: It was observed that the first branch was the central retinal artery in 23 orbits (56\%), the posterior ciliary arteries in 14 orbits (34\%), the lacrimal artery in three orbits (7\%) and the supraorbital artery in one orbit (3\%).

Conclusion: It was observed that the first branch of the ophthalmic artery was the central retinal artery or posterior ciliary arteries substantially. Both arteries are essential for vision and are very important to be protected in surgeries involving this area.

Keywords: Ophthalmic artery, central retinal artery, posterior ciliary arteries, lacrimal artery

\section{ÖZET}

Amaç: Arteria ophthalmica ve dalları en karmaşık anatomiye ve embriyolojiye sahip arterlerden biridir. Bu arterin dallarıly ilgili birçok çalışma yapılmış olsa da, ilk dalı hakkında farklı kaynaklarda farklı sonuçlar bulunmaktadır. Bu nedenle bu çalışmada arteria ophthalmica'nın ilk dalının araştııılması amaçlandı.

Gereç ve Yöntem: İstanbul Tıp Fakültesi Anatomi Anabilim DaIı'nda bulunan kadavralara ait olan 41 orbita incelendi.

Bulgular: Yirmi üç orbitada (\%56) a. centralis retinae'nin, 14 orbitada (\%34) aa. ciliares posteriores'in, üç orbitada (\%7) a. lacrimalis'in ve bir orbitada (\%3) a. supraorbitalis'in ilk dal olduğu gözlendi.

Sonuç: Arteria ophthalmica'nın ilk dalının yüksek oranda a. centralis retinae ya da aa. ciliares posteriores olduğu görüldü. Her iki arter de görme için temeldir ve bu bölgeyi ilgilendiren cerrahilerde bu arterlerin korunması oldukça önemlidir.

Anahtar Kelimeler: Arteria ophthalmica, arteria centralis retinae, arteriae ciliares posteriores, arteria lacrimalis

\section{INTRODUCTION}

The ophthalmic artery $(O A)$ is the first intracranial branch of the internal carotid artery (ICA) (1). After originating from the ICA, it takes a short course in the cranium and then passes through the optic canal and enters the orbit. Here it gives branches that supply the eyeball, optic nerve $(\mathrm{ON})$ and periophthalmic tissues such as eyelids, lacrimal gland and extraocular muscles.
Embryologically, the OA develops from three different arterial sources. Situations such as non-fusion of these arteries or persistence of the arteries that need to be regressed cause variations in the origin or branching of the $\mathrm{OA}$, and these have been widely stated in the literature. These variations have been reported to pose a potential risk in craniotomy or endovascular treatment, such as obliteration of the middle meningeal artery, dural arte-

Corresponding author/iletişim kurulacak yazar: gayretli@istanbul.edu.tr

Submitted/Başvuru: 19.04.2021 • Accepted/Kabul: 26.05.2021 • Published Online/Online Yayın: 06.09.2021 
riovenous shunt, tumor or epistaxis $(2,3)$. Therefore, the importance of $\mathrm{OA}$ anatomy has increased during the last decades for ophthalmologists, neurosurgeons and interventional neuroradiologists (4).

Branches of the OA are the central retinal artery (CRA), posterior ciliary arteries (PCA), lacrimal artery (LA), muscular branches, anterior and posterior ethmoidal arteries, palpebral arteries, supraorbital artery (SA) and its terminal branches, the dorsal nasal artery and frontal artery. It has been stated that CRA is the first branch of the OA with a frequency varying from $67 \%$ to $77.5 \%(1,5)$. In cases where the CRA is the second or third branch, the probable first branch has been reported as the PCA (5). The CRA and PCA supply the retina and choroid respectively and therefore have been noted as critical in vision (1). For these reasons, it was aimed to investigate the morphology and morphometry of the $\mathrm{OA}$ and its first branch.

\section{MATERIALS AND METHOD}

The first branch of the OA was evaluated on 41 cadavers. All specimens were obtained from the Department of Anatomy of Istanbul Faculty of Medicine. All dissections were performed on cadavers used in undergraduate and post-graduate medical training. All cadavers were preserved with a formalin-ethanol-glycerin-phenol solution and kept in cold storage $\left(5-8^{\circ} \mathrm{C}\right)$ after embalming.

The dissection process was carried out by preserving the integrity of the orbit and its internal structures, starting from the intracranial opening of the optic canal. When silicone injection was completed, the orbital roof and the bony structure of the optic canal were removed with precision and the orbit was reached (Figure 1). The OA

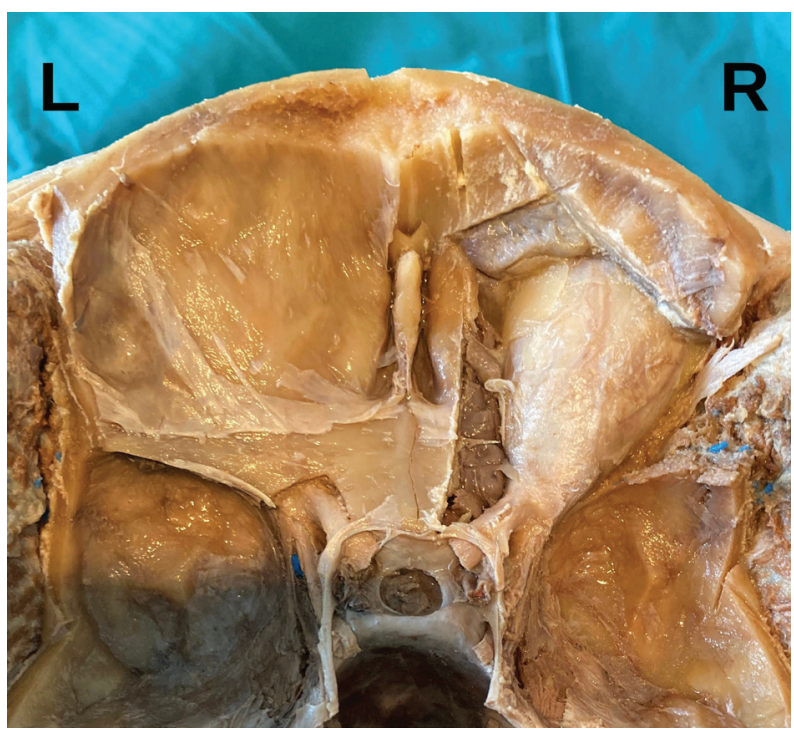

Figure 1: Exposition of orbita after removal of orbital wall L: left, R: right

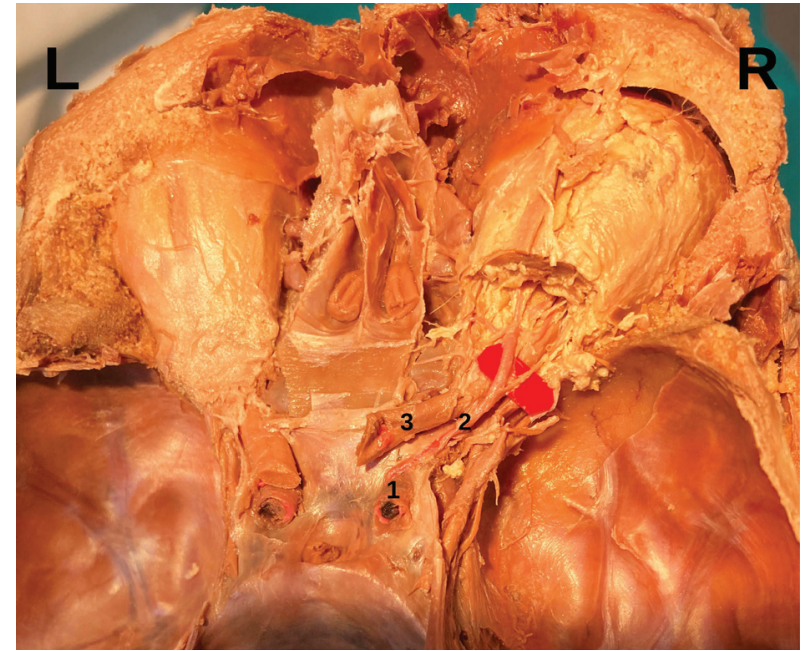

Figure 2: The dissection procedure of branches of ophthalmic artery

1: internal carotid artery, 2: ophthalmic artery, 3: optic nerve, L: left, R: right

and its branches and the ON were separated from other intraorbital structures by making delicate dissections, and were followed and recorded for each orbit until the OA gave its end branches (Figure 2). A total of 41 ophthalmic arteries were included in the present study of which 19 were bilateral and three were one-sided. The reason why those three arteries were studied unilaterally was that those three cadavers could not be evaluated bilaterally during dissection. The branches of the OA were evaluated after the colored latex silicone injection was made.

Ethical committee approval (Date: 16.04.2021, No: 172684) was obtained for our study.

\section{RESULTS}

In this study, the first branch was observed to be originating from the OA during its course in the orbital cavity. It was determined that the most frequent first branch of the OA was the CRA with a rate of $56 \%(n=23)$ (Figure 3$)$. In total, 12 of the 23 CRA's were in the left orbit and 11 were in the right orbit. The CRA emerged as the first branch bilaterally in nine cadavers (totally 18), consequently the remaining five CRA were determined unilaterally in five cadavers. The second most frequent first branch was the PCA, observed in 14 orbits (34\%) (Figure 4). Of these 14 arteries, eight were bilaterally (in four cadavers) and six were unilaterally traced as the first branch in dissected specimens. In those six cadavers, which had the PCA as the first branch of the OA unilaterally, on the contralateral side, the SA was the first branch in one case, the first branch could not be evaluated in one case and the CRA was the first branch in the remaining orbit $(n=3)$. The third most common first branch was the LA with a rate of $7 \%$ 


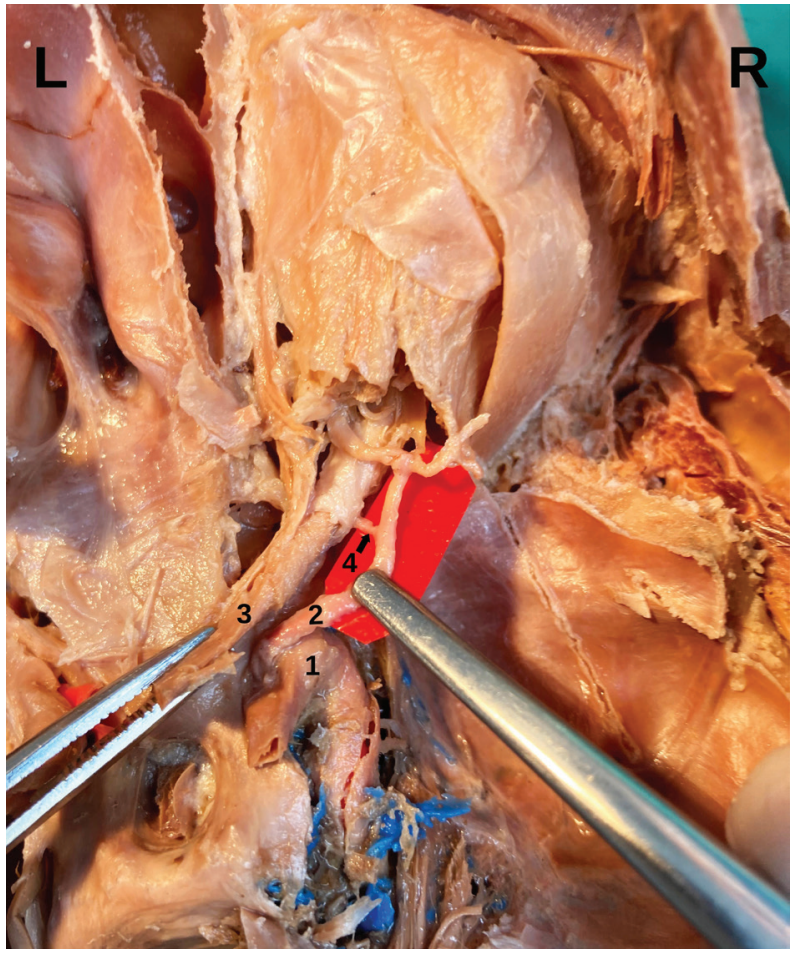

Figure 3: Exposition of central retinal artery as the first branch of ophthalmic artery

1: internal carotid artery, 2: ophthalmic artery, 3: optic nerve, 4: central retinal artery, L: left, R: right

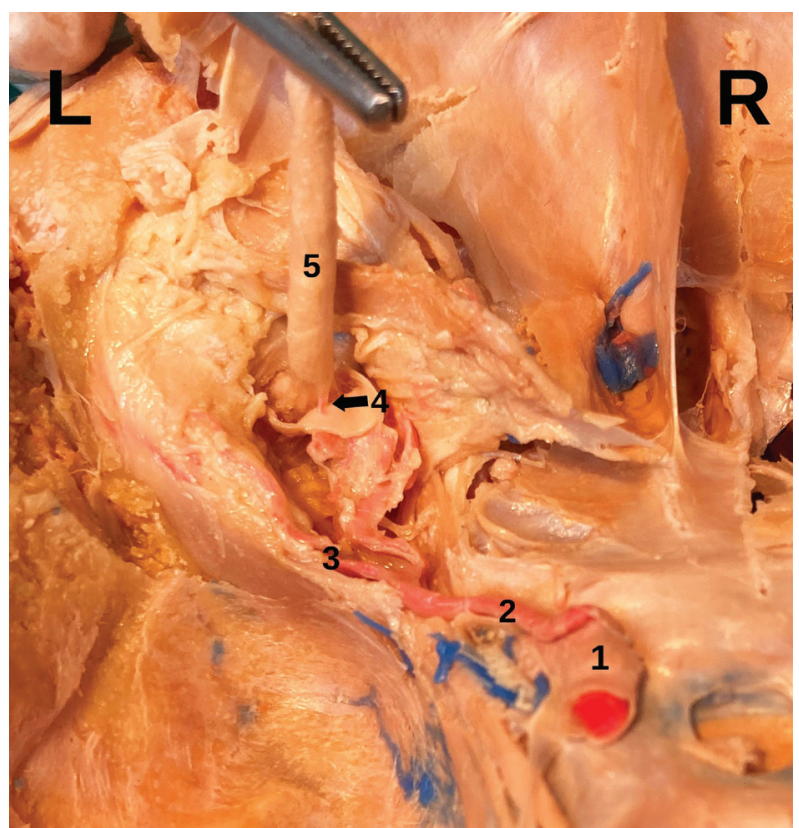

Figure 5: Exposition of lacrimal artery as the first branch of ophthalmic artery

1: internal carotid artery, 2: ophthalmic artery, 3: lacrimal artery, 4: central retinal artery, 5: optic nerve, L: left, R: right

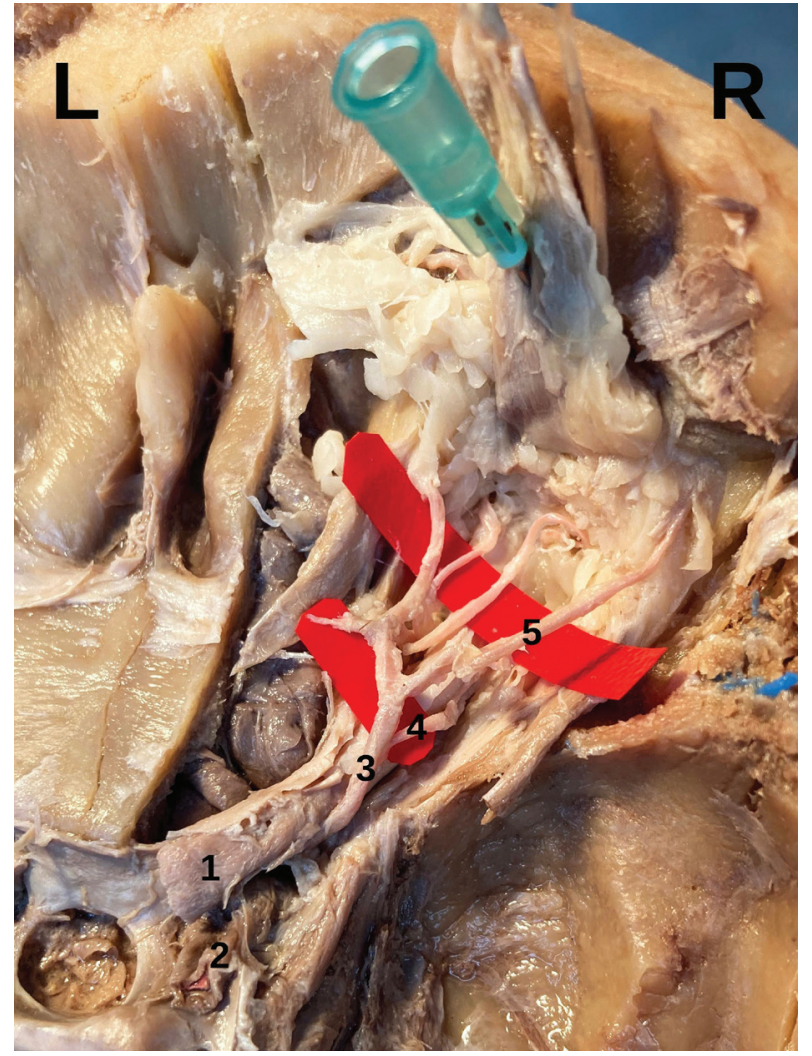

Figure 4: Exposition of posterior ciliary arteries as the first branch of ophthalmic artery

1: optic nerve, 2: internal carotid artery, 3: ophthalmic artery, 4: posterior ciliary arteries, 5: lacrimal artery, L: left, R: right

$(n=3)$ (Figure 5). Two of these three arteries were bilateral (in one cadaver) and the remaining artery was seen on the left side of one specimen. Finally, the least common (3\%) first branch of the OA was the SA $(n=1)$. Unfortunately we could not take a photograph of the cadaver which had the SA as a first branch unilaterally because when we passed on to the photograph taking stage of

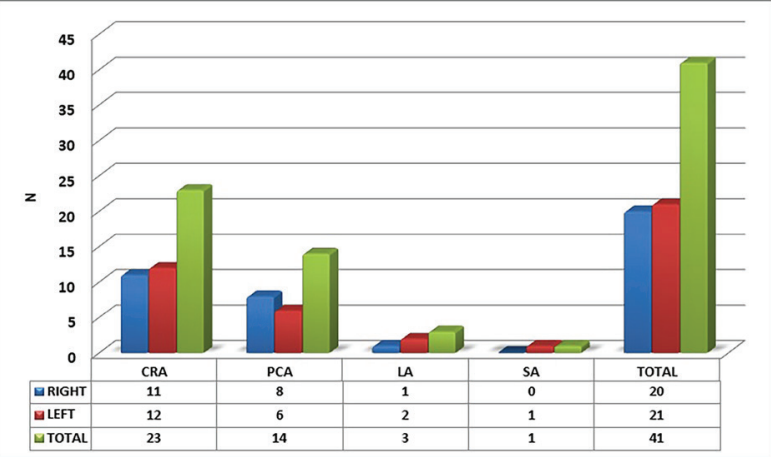

Figure 6: Numbers of different first branches of ophthalmic artery

CRA: central retinal artery, PCA: posterior ciliary arteries, LA: lacrimal artery, SA: supraorbital artery 
Table 1: Numbers of each first branches originating from the ophthalmic artery, according to sides

\begin{tabular}{|c|c|c|}
\hline \multirow{2}{*}{ No } & \multicolumn{2}{|c|}{ The first branch of ophthalmic artery } \\
\hline & Left & Right \\
\hline 1 & CRA & CRA \\
\hline 2 & CRA & CRA \\
\hline 3 & LA & PCA \\
\hline 4 & PCA & PCA \\
\hline 5 & CRA & CRA \\
\hline 6 & CRA & CRA \\
\hline 7 & PCA & PCA \\
\hline 8 & CRA & CRA \\
\hline 9 & PCA & PCA \\
\hline 10 & PCA & PCA \\
\hline 11 & SA & PCA \\
\hline 12 & LA & LA \\
\hline 13 & PCA & CRA \\
\hline 14 & CRA & CRA \\
\hline 15 & CRA & PCA \\
\hline 16 & PCA & CRA \\
\hline 17 & CRA & CRA \\
\hline 18 & CRA & CRA \\
\hline 19 & CRA & CRA \\
\hline 20 & $\begin{array}{l}\text { Couldn't be } \\
\text { evaluated }\end{array}$ & PCA \\
\hline 21 & CRA & $\begin{array}{l}\text { Couldn't be } \\
\text { evaluated }\end{array}$ \\
\hline 22 & CRA & $\begin{array}{l}\text { Couldn't be } \\
\text { evaluated }\end{array}$ \\
\hline
\end{tabular}

CRA: Central retinal artery, LA: Lacrimal artery, PCA: Posterior ciliary arteries, SA: Supraorbital artery

the study, we were faced with the fact that it had been harmed during routine practices. The numbers of each first branch originating from the $\mathrm{OA}$, according to sides, are given in Figure 6. Additionally, our results concerning the first branch of the OA of each cadaver are given in Table 1.

\section{DISCUSSION}

Orbital dissection was first described by the German anatomist Meyer in 1887 (6). Meyer revealed the anatomical branching pattern and variations of the $\mathrm{OA}$ in a series of over 20 cases. Then, in a 3-series study conducted in 1962 by the ophthalmologist Sohan Sing Hayreh, the origin, course and branches of the OA were investigated (7-9).
Around the same time period, Kuru, Moret, Vignaud, and Lasjaunias were also initiators in this field with their angiographic studies (10-13).

Knowledge of the embryological development of the OA is essential to understand its origin variations. It is stated that the $O A$ is the craniofacial artery which has the most complex embryological development (4). The primitive $O A$ is mainly formed by the primitive ventral ophthalmic artery (PVOA), the primitive dorsal ophthalmic artery (PDOA) and stapedial artery. In the 4-6 mm (crown-rump length) embryo, PDOA formation is observed from the bifurcation point of the primitive carotid artery in its caudal and cranial division (origin of the future PCA). The PDOA enters the orbit from the superior orbital fissure. At the 7-12 mm stage, the PVOA artery emerges from the cranial division of the primitive carotid artery and enters the orbit through the optic canal. At the 16-18 mm stage, the PVOA and PDOA combine to form the permanent stem of the primitive $O A$. In the $18-40 \mathrm{~mm}$ embryo, the stapedial artery is divided into maxillomandibular and supraorbital divisions. The maxillomandibular artery anastomoses with the pharyngeal arteries by extending beyond the head from the spinous foramen. The SA enters the orbit and divides into two branches called the ethmoidonasal and lacrimal arteries. The ethmoidonasal artery joins with the primitive $O A$ at the level of the arterial ring around the $\mathrm{ON}$. Thus, at the $40 \mathrm{~mm}$ stage, the $\mathrm{OA}$ reaches its adult configuration $(1,3,4,13)$.

This model explains most cases of the variant OA origin through migration, partial/complete regression, and persistence of primitive vessels, and/or remaining anastomotic loops (1).

The OA originates from the intradural part of the ICA (1, $4,14,15)$. In fact, there are many studies stating that they have not observed any source of origin other than the intracranial (intradural) segment of the ICA $(5,16-19)$. Also in this study, all of the examined ophthalmic arteries have originated from the intracranial segments of the ICA: distal to cavernous sinus.

For the purpose of description and clinical points of view, the ICA has been divided into 7 parts by neurosurgeon Bouthillerin in 1996 (20). According to this, the ICA is divided into its $1^{\text {st }}$ or cervical segment, $2^{\text {nd }}$ or petrous segment that gives origin to the caroticotympanic and vidian artery, $3^{\text {rd }}$ or lacerum segment, $4^{\text {th }}$ or cavernous segment that provides the meningohypophyseal and inferolateral trunk, $5^{\text {th }}$ or clinoid segment, $6^{\text {th }}$ or ophthalmic segment that gives the OA and superior hypophyseal artery, and $7^{\text {th }}$ or communicating segment where the ICA, before its final division, gives origin to the anterior choroidal and posterior communicating artery (20). According to this classification, which is commonly used by surgeons and radiologists, the $\mathrm{OA}$ is defined as the first branch orig- 
inating from the $\mathrm{C} 6$ segment of the ICA. Consequently the $O A$ is also defined as the first intracranial or intradural branch of the ICA (1). Later, in 2009, Lehecka et al. divided the $\mathrm{C} 4$ segment into 3 portions as ophthalmic, communicating and choroid (21).

As the most common origin variation of the OA reported in the literature, it originates from the $\operatorname{MMA}(1,3,15)$. The MMA origin of the OA could be explained by: the absence of anastomosis between the supraorbital branch and the $\mathrm{OA}$, or the persistence of the proximal stem of the supraorbital branch of the stapedial artery with regression of the primitive OA (4).

It has been reported that an OA originating from the cavernous part of the ICA is a rare variation and its incidence is estimated at $0.4 \%$ (22). In addition, Dilenge, Fiore, Parlato, Islak and Indo have also defined cases with the OA of cavernous ( $4^{\text {th }}$ segment) origin (23-27). Toma reported that the $O A$ arising from the cavernous segment of the ICA was defined as the second most common variation and added that this artery entered the orbit from the superior orbital fissure (3). Lasjaunias explained this variation by the embryological regression in the PVOA instead of the PDOA. In other words, this anatomical variation is explained by the embryological persistent PDOA (13).

In addition, origin of the OA from the clinoidal $\left(5^{\text {th }}\right.$ segment) or communicating portions $\left(7^{\text {th }}\right.$ segment) of the ICA has been recorded $(3,14,28,29)$.

The double origin of the OA is a very rare variant; its incidence is estimated to be around $0.2 \%$, and only a few studies have been reported $(4,13,22,30,31)$. Lasjaunias explained this variation by the lack of an anastomotic ring around the ON between the PDOA and the PVOA, or persistence of both of these arteries $(1,4,13)$.

The rare origin variation of the OA from the MCA has been observed in the absence of the ICA $(15,32-34)$.

There have been reports of the ophthalmic artery originating from the ACA $(27,35-37)$. This variation corresponds to the persistence of the PVOA (1).

It has been reported that it is encountered in the presence of ICA agenesis or hypoplasia (38-40).

OA originating from the basilar artery is an extreme variation. It has been stated that current embryological theories do not provide a satisfactory explanation for this formation (41-43).

OA originating from this artery has been reported in only 1 case (44).

After its origin, the OA follows a short intracranial course until it pierces the dura mater and reaches the optic ca- nal. The course of the OA between its origin and optic canal is named as the intracranial course. This distance was calculated by Hayreh and Dass as $0.5-0.95 \mathrm{~mm}$ (8). Although the intracranial course of the $O A$ is short, the knowledge of the anatomy of this course is of utmost surgical importance as surgical intervention for $O A$ aneurysms takes place at that area (1).

After the intracranial course, the OA enters the optic canal together with the ON. This portion is defined as intracanalicular course.

Afterwards the OA exits the optic canal and enters the orbit. This is the intraorbital part of the OA. The intraorbital course of the OA divides into three segments. In the first segment, the $O A$ exits the optic canal and proceeds parallel to the ON. The second segment courses medially passing above (83\%) or below (17\%) the ON (1). Finally, the third segment is separated to its branches medially to the $\mathrm{ON}$, and terminates at the superomedial angle of the orbital opening $(3,4,9)$.

Hayreh, who studied the OA branches in the orbits of 59 human cadavers, reported that localization and order of origin of these branches are not identical on either side of the same person (9). It is therefore stated that the branching patterns of the $O A$ are very complex and unique.

Two different types of branching have been defined as the OA passes above or below the ophthalmic nerve ( 9 , 15). According to this classification, if the OA crosses over the $\mathrm{ON}$, the first branch is the medial posterior ciliary arteries (MPCA) in common with the CRA; if the OA crosses under the $\mathrm{ON}$, the first branch is the lateral posterior ciliary arteries (LPCA). However, when the literature was examined, it was observed that there were branching patterns that did not fit this classification. Each most frequent first branch of the OA determined in our study is discussed separately.

The CRA is the most frequent first branch of the OA. It supplies blood to the retina, therefore it is critical for vision (1). It is one of the smallest branches of the OA and is a terminal artery. Due to its average diameter of $0.36 \mathrm{~mm}$, the CRA is highly susceptible to occlusion (45). The CRA is commonly the first location where ischemic or embolic events make us notice the fact that there is serious vascular disease and high risk for an upcoming stroke. A central retinal artery embolus may produce a transient blindness in the affected eye, called amaurosis fugax, which lasts for several minutes but less than an hour (transient ischemic attack) (46). The CRA occlusion causes ischemia and results in infarction of the retina and as a result, sudden loss of vision with an incidence of $1-8 / 100,000$ people occurs (1). Therefore, damage of the CRA usually results in blindness (18). 
In the study by Tsutsumi et al. the CRA was found to be the first branch of the OA in $67 \%$, the second branch in $28 \%$ and the third branch in $5 \%$ of the orbits they examined (5). In the present study, the CRA was observed as the first branch in $56 \%$ of cases.

The PCA are branches of the OA, ranging in number from 1 to 5 , that supply the choroid and outer layer of the retina. It has been reported that in $80 \%$ of cases there are 2 or 3 PCA (1). The PCA are named as medial or lateral according to their location. Ciliary arteries supply the middle vascular tunic. Moreover, they take part in blood supply of the retina; if a detached retina occurs, this component of blood supply may be disrupted (46).

According to Hayreh, the first branch is either the CRA in common with the MPCA or only the LPCA $(9,15)$. In our study, the PCA were observed as the first branch with a frequency of $34 \%$, as the second most frequent first branch of the OA.

The LA supplies the lacrimal gland, lateral rectus muscle, lateral part of the eyelids and gives off meningeal branches to dura mater (4). The LA is often referred to as the third or fifth branch of the OA (9). When the literature was reviewed, no case was observed in which the LA was reported to be the first branch of the OA. Therefore, this paper is the first one, in which the LA is reported to be the first branch of the OA ( $7 \%$ cases, $n=3)$.

One of the limitations of our study is that we could not take a photograph of the cadaver which had the SA as a first branch. Moreover, we could not describe the practical locations for determining the first branch of the OA of the related region for surgeons.

In conclusion, the anatomy of the $\mathrm{OA}$ is quite complicated because it originates from three embryological sources, has a dual intracranial and extracranial course, and both itself and its branches are small in size. In addition, the location and proximity of structures such as the ON, and the critical importance of the CRA and PCA, which are usually the first branches of the $O A$, cause difficulties in surgical operations in this area. Knowledge of the anatomy and possible variations of the OA and its branches is essential for neurosurgeons and neuroradiologists while approaching pathologies such as retinoblastoma and CRA occlusion $(5,45)$.

Ethics Committee Approval: This study was approved by the Clinical Research Ethical Committee of the Istanbul University, Istanbul Faculty of Medicine (Date: 16.04.2021, No: 172684).

Peer Review: Externally peer-reviewed.

Author Contributions: Conception/Design of Study- Ö.G.; Data Acquisition- A.K.; Data Analysis/Interpretation- Ö.G.; Draf- ting Manuscript- Ö.G.; Critical Revision of Manuscript- O.C.; Final Approval and Accountability- Ö.G., A.K., O.C., A.Ö., B.B.

Conflict of Interest: Authors declared no conflict of interest.

Financial Disclosure: Authors declared no financial support.

Etik Komite Onayı: Bu çalışma için etik komite onayı İstanbul Üniversitesi, İstanbul Tıp Fakültesi Klinik Araştırmalar Etik Kurulu'ndan alınmıştır (Tarih: 16.04.2021, No: 172684).

Hakem Değerlendirmesi: Dış bağımsız.

Yazar Katkıları: Çalışma Konsepti/Tasarım- Ö.G.; Veri ToplamaA.K.; Veri Analizi/Yorumlama- Ö.G.; Yazı Taslağı- Ö.G.; İçeriğin Eleştirel İncelemesi- O.C.; Son Onay ve Sorumluluk- Ö.G., A.K., O.C., A.Ö., B.B.

Çıkar Çatışması: Yazarlar çıkar çatışması beyan etmemişlerdir.

Finansal Destek: Yazarlar finansal destek beyan etmemişlerdir.

\section{REFERENCES}

1. Michalinos A, Zogana S, Kotsiomitis E, Mazarakis A, Troupis T. Anatomy of the ophthalmic artery: a review concerning its modern surgical and clinical applications. Anat Res Int 2015;2015:591961. [CrossRef]

2. Hayashi N, Kubo M, Tsuboi $Y$, Nishimura S, Nishijima M, Ahmed Abdel-Aal M, et al. Impact of anomalous origin of the ophthalmic artery from the middle meningeal artery on selection of surgical approach to skull base meningioma. Surg Neurol 2007;68(5):568-72. [CrossRef]

3. Toma N. Anatomy of the ophthalmic artery: embryological consideration. Neurol Med Chir (Tokyo) 2016;56(10):585-91. [CrossRef]

4. Bonasia S, Bojanowski M, Robert T. Embryology and anatomical variations of the ophthalmic artery Neuroradiology 2020;62(2):139-52. [CrossRef]

5. Tsutsumi S, Rhoton AL Jr. Microsurgical anatomy of the central retinal artery. Neurosurgery 2006;59(4):870-9. [CrossRef]

6. Meyer F. Zur anatomie der Orbitalarteien. Morph Jahr 1887; 12:414-58.

7. Hayreh SS, Dass R. The ophthalmic artery: I. Origin and intra-cranial and intra-canalicular course. $\mathrm{Br} J$ Ophthalmol 1962;46(2):65-98. [CrossRef]

8. Hayreh SS, Dass R. The ophthalmic artery: II. Intra-orbital course. Br J Ophthalmol 1962;46(3):165-85. [CrossRef]

9. Hayreh SS. The ophthalmic artery: III. Branches. Br J Ophthalmol 1962;46(4):212-47. [CrossRef]

10. Kuru Y. Meningeal branches of the ophthalmic artery. Acta Radiol Diagn (Stockh) 1967;6(3):241-51. [CrossRef]

11. Moret J, Lasjaunias P, Théron J, Merland JJ. The middle meningeal artery. Its contribution to the vascularisation of the orbit. J Neuroradiol 1977;4(2):225-48.

12. Vignaud J, Hasso AN, Lasjaunias P, Clay C. Orbital vascular anatomy and embryology. Radiology 1974;111(3):617-26. [CrossRef]

13. Lasjaunias P, Brismar J, Moret J, Théron J. Recurrent cavernous branches of the ophthalmic artery. Acta Radiol Diagn (Stockh) 1978;19(4):553-60. [CrossRef] 
14. Perrini P, Cardia A, Fraser K, Lanzino G. A microsurgical study of the anatomy and course of the ophthalmic artery and its possibly dangerous anastomoses. J Neurosurg 2007;106(1):142-50. [CrossRef]

15. Hayreh SS. Orbital vascular anatomy. Eye (Lond) 2006;20(10):1130-44. [CrossRef]

16. Komai K, Miyazaki S, Onoe S, Shimo-Oku M, Hishida S. Vasomotor nerves of vessels in the human optic nerve. Acta Ophthalmol Scand 1995;73(6):512-6. [CrossRef]

17. Oikawa S, Kawagishi K, Yokouchi K, Fukushima N, Moriizumi T. Immunohistochemical determination of the sympathetic pathway in the orbit via the cranial nerves in humans. J Neurosurg 2004;101(6):1037-44. [CrossRef]

18. Rhoton AL Jr. The orbit. Neurosurgery 2002;51(4):303-34. [CrossRef]

19. Ruskell GL. Access of autonomic nerves through the optic canal, and their orbital distribution in man. Anat Rec A Discov Mol Cell Evol Biol 2003;275(1):973-8. [CrossRef]

20. Bouthillier A, van Loveren HR, Keller JT. Segments of the internal carotid artery: a new classification. Neurosurgery 1996;38(3):425-33. [CrossRef]

21. Lehecka M, Dashti R, Romani R, Celik O, Navratil O, Kivipelto $L$, et al. Microneurosurgical management of internal carotid artery bifurcation aneurysms. Surg Neurol 2009;71(6):649-67. [CrossRef]

22. Bertelli E, Regoli M, Bracco S. An update on the variations of the orbital blood supply and hemodynamic. Surg Radiol Anat 2017;39(5):485-96. [CrossRef]

23. Dilenge D, Ascherl GF Jr. Variations of the ophthalmic and middle meningeal arteries: relation to the embryonic stapedial artery. AJNR Am J Neuroradiol 1980;1(1):45-54.

24. Fiore DL, Pardatscher K, Fiore D, Zuccarello M, Iraci G. Persistent dorsal ophthalmic artery. Report of a case with associated fibromuscular hyperplasia of the extracranial internal carotid artery and multiple cerebral aneurysms. Neurochirurgia (Stuttg) 1981;24(3):106-8. [CrossRef]

25. Parlato $C$, di Nuzzo G, Luongo M, Tortora F, Briganti F. Anatomical variant of origin of ophthalmic artery: case report. Surg Radiol Anat 2011;33(3):275-8. [CrossRef]

26. Islak C, Ogüt G, Numan F, Cokyüksel O, Kuday C. Persistent nonmigrated ventral primitive ophthalmic artery. Report on one case. J Neuroradiol 1994;21(1):46-9.

27. Indo M, Oya S, Tanaka M, Matsui T. High incidence of ICA anterior wall aneurysms in patients with an anomalous origin of the ophthalmic artery: possible relevance to the pathogenesis of aneurysm formation. J Neurosurg 2014;120(1):93-8. [CrossRef]

28. Zhou WZ, Zhao LB, Liu S, Shi HB. Teaching Neurolmages: Unilateral agenesis of internal carotid artery with ophthalmic artery from opposite side. Neurology 2015;84(9):e65-6. [CrossRef]

29. Baltsavias G, Türk $Y$, Valavanis A. Persistent ventral ophthalmic artery associated with supraclinoid internal carotid artery aneurysm: case report and review of the literature. J Neuroradiol 2012;39(3):186-9. [CrossRef]

30. Bracard S, Liao L, Zhu F, Gory B, Anxionnat R, Braun M. The ophthalmic artery: a new variant involving two branches from the supracavernous internal carotid artery. Surg Radiol Anat 2020;42(2):201-5. [CrossRef]
31. Watanabe A, Hirano K, Ishii R. Dural caroticocavernous fistula with both ophthalmic arteries arising from middle meningeal arteries. Neuroradiology 1996;38(8):806-8. [CrossRef]

32. Fisher AG. A case of complete absence of both internal carotid arteries, with a preliminary note on the developmental history of the stapedial artery. J Anat Physiol 1913;48:37-46.

33. Flemming EE. Absence of the left internal carotid artery. J Anat Physiol 1895;29:13-4.

34. Lowrey LG. Anomaly in the circle of Willis, due to absence of the right internal carotid artery. Anat Rec 1916;10:221-2.

35. Honma Y, Ogawa T, Nagao S. Angiographically occult anomalous ophthalmic artery arising from the anterior cerebral artery. Acta Neurochir (Wien) 1997;139(5):480-1. [CrossRef]

36. Li Y, Horiuchi T, Yako T, Ishizaka S, Hongo K. Anomalous origin of the ophthalmic artery from the anterior cerebral artery. Neurol Med Chir (Tokyo) 2011;51 (8):579-81. [CrossRef]

37. Hannequin P, Peltier J, Destrieux C, Velut S, Havet E, Le Gars D. The inter-optic course of a unique precommunicating anterior cerebral artery with aberrant origin of an ophthalmic artery: an anatomic case report. Surg Radiol Anat 2013;35(3):269-71. [CrossRef]

38. Naeini RM, De J, Satow T, Benndorf G. Unilateral agenesis of internal carotid artery with ophthalmic artery arising from posterior communicating artery. AJR Am J Roentgenol 2005;184(2):571-3. [CrossRef]

39. Nakata H, Iwata Y. Agenesis of the left internal carotid artery with an ophthalmic artery arising from the posterior communicating artery. No Shinkei Geka 1987;15(1):57-62.

40. Priman J, Christie DH. A case of abnormal internal carotid artery and associated vascular anomalies. Anat Rec 1959;134:87-95. [CrossRef]

41. Sade B, Tampieri D, Mohr G. Ophthalmic artery originating from basilar artery: a rare variant. AJNR Am J Neuroradiol 2004;25(10):1730-1.

42. Schumacher M, Wakhloo AK. An orbital arteriovenous malformation in a patient with origin of the ophthalmic artery from the basilar artery. AJNR Am J Neuroradiol 1994;15(3):550-3.

43. Rivera R, Choi IS, Sordo JG, Giacaman P, Badilla L, Bravo $E$, et al. Unusual origin of the left ophthalmic artery from the basilar trunk. Surg Radiol Anat 2015;37(4):399-401. [CrossRef]

44. Tonetti DA, Jadhav AP, Ducruet AF. A rare marginal tentorial artery to ophthalmic artery anastomosis. J Clin Neurosci 2015;22(4):773-4. [CrossRef]

45. Baldoncini M, Campero A, Moran G, Avendaño M, Hinojosa-Martínez P, Cimmino M, et al. Microsurgical Anatomy of the Central Retinal Artery. World Neurosurg 2019;130:e172-e187. [CrossRef]

46. Felten DL, O'Banion MK, Maida MS, Netter F. Netter's Atlas of Neuroscience. Section III Systemic neuroscience 14-Sensory Systems. Philedelphia, PA: Elsevier; Third Edition 2016: 353-89. [CrossRef] 